\title{
Uma Lei Contra o Crime Escravista e o Mal-Estar da Abolição
}

\author{
Renato Sarieddine Araújo ${ }^{1}$ \\ ${ }^{1}$ Universidade Federal de Minas Gerais, MG, Brasil
}

Resumo: Este ensaio teórico discute alguns fatos ligados à abolição da escravidão no Brasil, o mais importante acontecimento simbólico da história brasileira, visto que representa a principal transformação das regras da sociedade. Os historiadores relatam, entretanto, que essa mudança foi profundamente amargada por antigos senhores: alguns sucumbiram de uma melancolia, culminando muitas vezes em morte para alguns, em loucura para outros e até mesmo em suicídios. Também se constatou uma segunda vertente do mal-estar entre os antigos senhores, este claramente criminoso: violências físicas e instrumentalização das instituições políticas, garantindo a manutenção da perseguição a pessoas de pele negra. O método utilizado neste artigo se inspira da antropologia psicanalítica de S. Freud e pretende analisar fatos históricos tendo como referência principalmente os textos metapsicológicos. Proponho uma leitura da dimensão inconsciente da reação antiabolicionista enraizada nas instituições da República. Em contraposição, discuto a necessidade de se instaurar uma legislação penal adequada que enquadre o escravismo transatlântico na história do Brasil. Para tal, me refiro à "Lei Taubira" promulgada na França em 2001, reconhecendo a escravização transatlântica como um crime contra a humanidade. A leitura do mal-estar e da nostalgia do senhor decaído aponta que o inconsciente criminoso demanda uma legislação adequada, uma ferramenta importante notadamente para o processo de responsabilização dos sujeitos e instituições em relação à história e seu mal-estar subjetivo, ainda atual.

Palavras-chave: Brasil, Escravismo, Criminologia psicanalítica, Abolição, Mal-estar.

\section{A Law Against the Crime of Slavery and the Abolition's Discontent}

\begin{abstract}
This theoretical essay discusses some facts related to the abolition of slavery in Brazil, the most important symbolic event in Brazilian history in that it represents the deepest transformation of social rules in the country. Historians report, nevertheless, that such change profoundly embittered former slave owners, to the extent that some of them succumbed to a state of what I would call melancholia, which led, in many cases, to death, madness and suicide. A second facet of the discontent among former slave owners, clearly a criminal one, was also identified, consisting of physical violence and the instrumentalization of political institutions, which ensured the maintenance of the persecution against dark-skinned people. The method utilized in this article is inspired by Sigmund Freud's psychoanalytic anthropology, and serves to analyze historical facts, having Freud's metapsychological texts as a main reference. I provide an interpretation of the unconscious dimension of the antiabolitionist backlash that grew roots in the institutions of the Republic. In contrast, this essay also discusses the need to introduce an adequate penal law that takes into consideration the transatlantic slavery in Brazilian history. I refer, here, to the "Taubira Law", promulgated in France in 2001, which acknowledges transatlantic slavery as a crime against humanity. The analysis of discontent and of the nostalgia of decaying slave owners indicates that the
\end{abstract}


criminal unconsciousness demands adequate legislation, a tool that is particularly important for the process of responsibilization of both subjects and institutions regarding history and its subjective discontent.

Keywords: Brazil, Slavery, Psychoanalytic criminology, Abolition, Discontent.

\title{
Una Ley Contra el Crimen Esclavista y el Malestar de la Abolición
}

\begin{abstract}
Resumen: Este ensayo teórico analiza algunos hechos relacionados con la abolición de la esclavitud en Brasil, el evento simbólico más importante de la historia brasileña por representar la principal transformación de las reglas de la sociedad. Sin embargo, los historiadores afirman que este cambio fue profundamente amargado por los antiguos señores: algunos han sucumbido a una melancolía, que culminó muchas veces en la muerte, en la locura e incluso el suicidio. También hubo una segunda línea de malestar entre los viejos señores, que es claramente criminal: las violencias físicas y la instrumentalización de las instituciones políticas, garantizando el mantenimiento de la persecución de los negros. Este artículo usó un método con base en la antropología psicoanalítica de S. Freud el cual pretende analizar los hechos históricos teniendo como referencia principal los textos metapsicológicos. Se propone realizar una lectura de la dimensión inconsciente de la reacción antiabolicionista presente en las instituciones de la República. En contraste, se discute la necesidad de establecer una legislación penal adecuada que considere la esclavitud transatlántica en la historia de Brasil. Para ello, se hace referencia a la "Ley Taubira" promulgada en Francia en 2001, la cual reconoce la esclavitud transatlántica como un crimen contra la humanidad. La lectura del malestar y la nostalgia del señor caído señala que el inconsciente criminal requiere una legislación adecuada, una herramienta importante para el proceso de responsabilización de los sujetos e instituciones ante la historia y su malestar subjetivo, que aún está vigente.
\end{abstract}

Palabras clave: Brasil, Esclavitud, Criminología psicoanalítica, Abolición, Malestar.

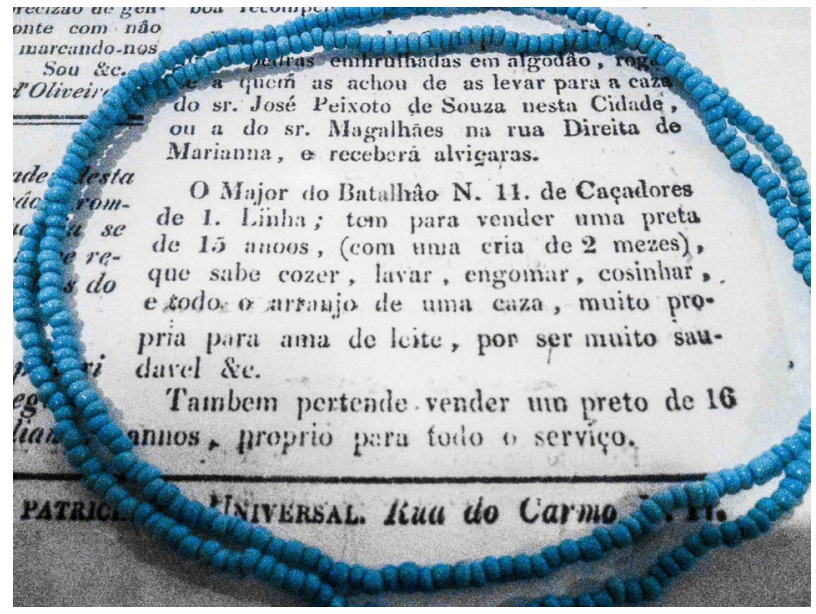

Figura 1

Jornal da Cidade de Ouro Preto de 1831 em obra de Isabel Löfgren e Patrícia Gouvêa (2017).

Fotografia de arquivo pessoal.

“... trata-se de uma análise, muito atual, quase política, você nem imagina".

(Freud, Zweig, 1973, p. 59, tradução nossa)

\section{A escravidão como um crime}

Em 1999, Christiane Taubira - então deputada francesa, originária da Guiana, eminente personalidade política e intelectual e futura Ministra da Justiça (2012-2016) - apresentava o projeto de lei n²001-434 (Loi n $\left.{ }^{\circ} 2001-434 \ldots, 2001\right)$. Entre outros pontos, determinava-se que a escravidão seria a partir de então reconhecida no código penal francês como um crime contra a humanidade.

Em um telejornal, a âncora perguntou à Taubira se a criação dessa lei era realmente necessária, ao que ela respondeu:

O Código Negro declarava o escravo como um bem móvel sobre quem o mestre tinha o direito, na primeira tentativa de fuga, de lhe cortar a orelha e de marcá-lo a ferro quente; na segunda, de lhe amputar parte da perna e marcá-lo a ferro quente; e na terceira, de matá-lo. Este Código Negro vigorou no direito francês por mais de dois 
séculos. Somente uma lei solene expressando o desejo do povo francês, dizendo claramente que a França, fiel ao que representa no imaginário universal, à sua reputação da pátria dos direitos do homem, poderia se opor. A França reconhece hoje que esse crime outrora legal, oficial e justificado, inclusive por textos eclesiásticos, é um crime cometido contra a humanidade (Taubira, 1999, tradução nossa).

A lei teria a força de se sobrepor ao real, destituindo um crime de sua natureza para lhe atribuir outra? Não. Entretanto, ela pode amparar um crime, como o escravismo. A lei Taubira se opõe a um grande equívoco legislativo da história francesa e evoca uma discussão clássica sobre a relação ambígua entre o crime e a lei. Antígona de Sófocles é talvez a maior referência ocidental sobre o tema. Lacan (1986) retomou a obra observando que Creonte impunha uma lei a partir de um equívoco sobre o que ele julgava ser o bem, a interdição do enterro de Polinice. Creonte acreditava que seus ideais eram mais elevados e justos que as leis divinas, transgredindo os limites do real. Esta tragédia grega coloca o fundamento da civilização diante do seu contrário, o crime - contra a lei dos deuses - imposta como lei. Uma inversão criminosa que corresponde aqui à legislação do escravismo praticada e legislada por um conjunto de instituições na França como no Brasil. Nesse sentido, a lei Taubira respira os ares soprados por Antígona e representa uma referência inicial para o trabalho de responsabilização - que será discutido adiante - ainda necessário às instituições.

No Brasil, algumas leis recentes, tal como a das cotas raciais, têm o intuito de reparação; elas seriam, portanto, fortalecidas de sentido com uma contextualização penal relativa à escravidão no Brasil. Ora, as medidas de reparação seriam estimuladas e mais consolidadas com a descrição e o reconhecimento formal do dano nas instâncias adequadas. A lei Taubira foi a primeira do tipo no mundo, a reconhecer a prática histórica da escravidão pelo que ela é do ponto de vista do direito penal. Inspirados, outros países também tomaram iniciativas análogas.".

Se, por inúmeras razões, a escravização precisa ser corretamente especificada na lei, o mesmo vale para seu contexto psicopatológico. Freud coloca a escravidão como um crime, entre os mais nefastos, no qual o criminoso busca satisfazer a necessidade de agressão sobre o próximo explorando seu trabalho sem compensação, usando-o sexualmente sem seu consentimento, se apropriando de seus bens, humilhando-o, infligindo-lhe sofrimentos, martirizando-o e lhe matando . . . justificando essa crueldade como necessária quando não é (Freud, 1929/2017, p. 56, tradução e grifos nossos).

Para Freud (1929/2017), entretanto, o ato criminoso depende de uma conjuntura psíquica mórbida, oriunda de um mal-estar decorrente de conflitos inconscientes. Estes envolvem identificações, recalque, ódio, amor, culpabilidade e angústia; e se o crime sinaliza o mal-estar do sujeito ou de uma cultura, a análise da melancolia de antigos senhores, frente à abolição, faz luz sobre o mal-estar gerador de criminalidade, motor do ódio racial do escravismo e seus restos atuais, tal qual testemunha o fato de que “[e]m 2017, 75,5\% das vítimas de homicídios foram indivíduos negros" (Instituto de Pesquisa Econômica Aplicada, 2019, p, 45). Um cronista resumiu o fato que será desenvolvido posteriormente: "houve suicídios de senhores de engenho: alguns enforcaram-se e outros se envenenaram, outros endoideceram" (Alves citado por Fraga Filho, 2007, p. 326).

\section{Culpabilidade, crime e mal-estar na História}

Segundo Assoun (1993, p. 61), a História coloca o psicanalista diante do

próprio objeto da Cultura como "texto": a "mitologia”, que exige um tipo de Dichtung [poesia]; como que o termo designa de "obra de arte de linguagem": um "povo" se define como um tal conjunto de "textos" e sua cultura como o "patrimônio" de mitos com o qual ele faz sua transmissão.

Já o interesse da análise da História para a cultura, continua Assoun (1993, p. 61, tradução nossa), se dá pela própria vocação da psicanálise de "escrever o 'poema' dos povos reescritos pelo saber do inconsciente". A escravidão coloca à prova este saber como um enigma cultural, que chamo aqui de melancolia do antigo senhor, e ao qual se presta para uma reflexão analítica. Não pretendo reduzir estes fatos a uma 
leitura psicanalítica, mas constatar o papel do inconsciente na história do escravismo brasileiro.

O mal-estar patológico se instala quando, diante das exigências da civilização, se faz uma troca infeliz do desejo por "satisfações substitutivas" (Freud, 1929/2017, p. 52, tradução nossa). Elas são ineficientes e nocivas, pois o recalque feito em nome da civili$z a c ̧ a ̃ o$ atiça a culpabilidade e a pulsão, em sua dimensão mais mortífera.

Segundo Freud (1929/2017), o sentimento de culpabilidade, do qual depende o mal-estar, é o grande entrave ao bem-estar individual e coletivo e o agenciador das neuroses, do sofrimento psíquico, das violências e dos crimes - entre os quais a instituição da escravidão. As instituições, as ideologias, a ciência, a arte e os ideais são importantes para a civilização, porque têm a força de manter a coesão social e propor vias sublimatórias para as pulsões. Entretanto, elas não curam o mal-estar e podem vacilar, funcionando nocivamente, inclusive contra a própria cultura e os laços de solidariedade, podendo ser até fonte dos crimes mais graves. A solução do recalque não é rara, pelo contrário, a "maioria das relações sociais se articulam em torno da renúncia pulsional, sendo essa a fonte da hostilidade que deve ser combatida por todas as civilizações" (Freud, 1929/2017, p. 41, tradução e grifo nossos).

Nesta passagem, citada acima, Freud emprega o termo Kulturversagung, se referindo a um fracasso das pulsões recalcadas, naufragadas em nome da cultura, e posteriormente satisfeitas em uma lógica nociva de culpabilidade. Essa pulsão insatisfeita pode retornar patologicamente contra o outro, ou contra o próprio sujeito, sendo

"introjetada" e direcionada ao lugar de origem, o próprio Eu. Ela é apropriada pelo "Supereu", uma parte do Eu, que vai se opor à outra parte. Obediente à "consciência moral", essa agressividade se satisfaz contra o Eu, como o sujeito gostaria de tê-la empregado sobre outros indivíduos (Freud, 1929/2017, p. 69, tradução nossa).

A "consciência moral" ou o argumento moralizante que o sujeito encontra para se desprezar, se prejudicar e até mesmo se suicidar, são manifestações do sentimento de culpabilidade. Ele guarda a mesma lógica quando se dirige ao outro e se impõe nas relações sociais, tornando-se a causa principal da morbidez social. Frente a essa culpabilidade, o sujeito regride suas satisfações pulsionais ao sintoma, deliberadamente sadomasoquistas e até criminosos. Entretanto, os sujeitos "não notam o sentimento de culpabilidade, mas um mal-estar doloroso, uma angústia” (Freud, 1929/2017, p. 80, tradução nossa). Freud insiste, caso seu leitor suponha que suas

reflexões sobre o sentimento de culpabilidade ultrapassem o tema deste ensaio [sobre o mal-estar na civilização] ou que tomem lugar demais, deixando para o segundo plano outros aspectos da questão ... , [para Freud, entretanto] o problema capital do desenvolvimento da civilização, é o sentimento de culpabilidade (Freud, 1929/2017, p. 79, tradução e grifo nossos).

\section{A cegueira do amor e o crime de massa}

Por que discutir o escravismo no Brasil tendo como objeto justamente o mal-estar de antigos senhores no momento da abolição? Afinal, eles são responsáveis pelo martírio de milhões de pessoas reduzidas à escravidão. $\mathrm{O}$ texto freudiano indica que a resposta a esta pergunta está nela mesma, pois, como vimos acima, a culpabilidade quando mórbida, é a fonte do crime, o "problema capital" da civilização. Trata-se, então, de abordar a escravidão pela patologia que é e que versa para o campo da criminologia.

A melancolia dos antigos senhores é um sintoma secundário que sucede ao crime do escravismo decorrente de um mal-estar na cultura ${ }^{1}$. A posição melancólica desses senhores indica que a satisfação sádica da pulsão, inicialmente voltada para a pessoa escravizada, foi revertida após a abolição e se dirigiu ao Eu.

A observação clínica de A. Aichhorn (1925/2005), pioneiro da criminologia psicanalítica, pode ser esclarecedora. Ele observou que a simples retirada dos meios que permitem ao sujeito cometer um crime não anula seu mal-estar, que ele chama de carência. Sem uma mudança subjetiva pela qual sujeito se torne responsável por suas moções inconscientes, o sintoma criminoso "toma nova direção e . . . se substitui

${ }^{1}$ O contexto cultural do mal-estar que antecede a escravidão brasileira é objeto da tese de doutorado de Araújo (2014) e não será desenvolvido aqui. 
por outro ... numa segunda edição das manifestações da carência" (Aichhorn, 1925/2005, p. 39, tradução nossa). O que dá a crer que o sintoma criminoso do antigo escravista continua em 'outras edições', melancólicas ou não.

Se Lacan (1966) humaniza o criminoso, ele confirma a responsabilidade do sujeito sobre as dificuldades impostas pelo Supereu, inclusive para o criminoso da massa ou do ideal. O Supereu, observou Lacan (1966), é esta "instância obscura, cega e tirânica . . . [que] está sempre pronta para emergir em desordem nas categorias sociais". A escravidão aparece então, como outros crimes, encarnada em "ideais de destruição, mostrando os feitos do Supereu no horizonte de fenômenos sociais de massa" (p. 137, tradução nossa). Lacan se referia a situações nas quais a lei se coloca como guardiã do crime, mas que nem por isso isentam o sujeito.

Para Lacan o crime de massa se opõe à responsabilidade do sujeito que se crê subtraído dela, atribuindo-a "ao grupo que dá cobertura ao indivíduo" (Lacan, 1966, p. 132, tradução nossa). Ele retomava o fato, descrito por Freud, relativo a ausência de remorso no crime de massa e cometido em nome do Ideal do Eu, o que supõe identificação e amor:

na cegueira do amor, o Ideal do Eu falha completamente: a crítica exercida por essa instância se cala, tudo o que faz e exige o objeto [amado] é inquestionável. A consciência moral [o sentimento de culpabilidade] se isenta frente a tudo o que é favorável ao objeto; na cegueira do amor nos tornamos criminosos sem remorso... [quando se faz] do objeto o Ideal do Eu (Freud, 1921/2002, p. 45, tradução e grifo nossos).

A complexidade da análise freudiana dos crimes de massa, cometidos "sem remorso", supõe a existência de um avesso do ódio, uma nostalgia, um "amor" ao objeto ao qual os membros do grupo se identificam. Como veremos a seguir, o antigo senhor melancólico, longe de sentir remorso pelos seus crimes, lamentou o fim da escravidão e alimentou uma nostalgia protetora deste ideal. Os homicídios cometidos por agentes do Estado sinalizam a recondução deste ideal. Tal é o caso do artifício "auto de resistência", que segundo

os ativistas do movimento negro brasileiro são as execuções sumárias perpetradas por agen- tes do Estado, sob a justificativa dos chamados "autos de resistência" ou "resistência seguida de morte". Esse é o ato administrativo concernente ao inquérito policial de homicídios cometidos por policiais a civis. De acordo com o art. 121 do Código Penal Brasileiro, para que seja registrado como "auto de resistência", o homicídio deve ter acontecido em suposta situação de confronto armado e em suposta legítima defesa, no cumprimento do dever policial. Ocorre que no momento em que o policial civil ou militar declara o homicídio como em decorrência de um confronto, no geral, a apuração do crime tende a ser dispensada e o caso é arquivado (Lemos, Aquime, Franco, \& Piani, 2017, p. 171-172).

\section{Celebração e lamento}

As comemorações iniciadas até mesmo antes do 13 de maio de 1888 se estenderam ininterruptamente por dias e noites. A massa desfilava eufórica em procissões, sambava e gritava, movida por uma energia incontida,

onda imensa de povo, notavam-se os homens negros, ... resplandecentes da luz da liberdade, fraternizando com a multidão que os recebia de braços abertos. Tinham a atitude ereta dos que já ousam olhar o céu ... e dos lábios entreabertos a escapar-se-lhes este grito ingente: - Viva a liberdade (Anais da Assembléia Legislativa Provincial da Bahia citados por Fraga Filho, 2010, p. 66).

Festejava-se o fim da lei da desigualdade nas relações de poder determinada por um critério racial. Mas nem todos comemoravam, como o comendador Aristides Novis, proprietário de plantação canavieira e comerciante, para quem a comemoração era "simplesmente insuportável” (Fraga Filho, 2007, p. 321). Os documentos atestam que, "do ponto de vista dos antigos proprietários, a abolição foi um traumatismo ... para alguns a vida não fazia mais qualquer sentido" (Fraga Filho, 2007, p. 326). Muitos antigos senhores interpretavam a celebração de maneira curiosa; para eles, "essa multidão descida à rua, composta em grande parte por esses que acabavam de escapar da escravidão, manifestava uma certa arrogância, premissa de perigosas consequências (Fraga Filho, 2007, p. 320). 
Novis escreve ao barão de Cotegipe no dia 16 de maio, dizendo se sentir ameaçado com a festa, pressentindo um perigo de morte e ironizando a abolição:

Viva o dia 13 de Maio, viva a abolição imediata e sem indenização, vieram enfim os salvadores da Pátria! Desde o dia 13 que vivemos em completo delírio! Comércio fechado todo o dia de ontem, passeatas pelas ruas, carros dos caboclos que foram buscar na Lapinha e depositaram na Praça do Palácio; enfim todas as noites temos grandes festas; carnaval, 2 de Julho, e festa da abolição! Faça ideia de um tempo, que efeito não produzem, temos aqui mais de 3 mil pretos vindos dos engenhos. Ainda ontem conversando com o presidente e Chefe de Polícia pedi-lhe que assim passassem estas festas, providenciasse no sentido destes trabalhadores voltarem às fazendas, se não em breve os roubos e mortes se dariam a cada momento (Novis, citado por Fraga Filho, 2010, p. 79-80).

A abolição também repercutiu muito mal no resto da família desse antigo senhor. Segundo Novis, o seu tio, o barão de Santiago, grande proprietário de Iguape, ficou "sorumbático, vendo sair para as ruas as suas crias que ele sempre tanto zelou" (Novis citado por Fraga Filho, 2010, p. 80). O historiador constata que Novis sentiu um profundo

desprazer vendo seus caros criados libertos de sua influência e tomando decisões alheios à sua opinião. Perplexo, o barão constatou que as formas tradicionais de controle servil se tornaram inúteis. Nesses primeiros dias de liberdade, até seu zelo paternalista pelos escravos domésticos foi inútil (Fraga Filho, 2007, p. 322).

Desolado, o barão decidiu mudar-se para Salvador, fugindo da "desordem" e da "desobediência" (Novis, citado por Fraga Filho, 2010, p. 81) que alcançaram seus domínios. No entanto, um de seus herdeiros diretos relatou que, chegando na sacada de sua casa em Salvador, o barão se deparou com

o imenso cortejo formado por libertos e populares que seguiu festivamente para render graças ao santo pela abolição da escravidão .... O barão não resistiu àquelas manifestações e aborrecido retornou a Iguape. Comparado ao que presenciara no seu engenho, a visão da multidão de libertos nas ruas talvez fosse mais assustadora. Conta-se que o barão sofreu grande abalo emocional vindo a morrer meses depois daqueles acontecimentos (Fraga Filho, 2010, p. 81-82).

\section{A nostalgia do pai e o ódio expiatório}

$\mathrm{Na}$ explicação mítica freudiana do fato social e do psiquismo do sujeito, há um ponto fundamental para essa reflexão: "passado um tempo do parricídio, houve uma escalada extraordinária da nostalgia do pai" (Freud, 1912/2013, p. 174, tradução nossa). Essa nostalgia aparece límpida nas memórias de Maria Augusta Bittencourt, que mesmo nascida após a abolição (1890), é nostálgica de seu pai, referido elogiosamente como "Senhor de escravos":

Meu pai firmou-se na ciência como médico. Fez construir uma estrada que rompeu o sertão baiano. Foi chamado o Mauá da Bahia. Imperador, Barões, Ministros de Estado não lhe negaram favores. Ganhou prestígio no Império. Prestígio que na República alargou o seu conceito. ... O seu retrato encima paredes e vai à praça pública levantar-se em busto de bronze como um Patriarca. Entretanto, nenhum ângulo de sua pujante carreira, nenhuma face de seus êxitos, aplausos que lhe palmilharam o caminho, despertam em mim maior admiração, maior orgulho do que a configuração moral em que o vejo como um Senhor de escravos (Maria Augusta Bittencourt, citada por Sacramento, 2007, p. 24).

A nostalgia pelo "Senhor de escravos" de Maria Augusta Bittencourt dá voz a uma cultura criminosa e sintomática nas relações sociais. Deste pensamento mórbido, próprio aos sujeitos identificados à uma certa cultura enraizada no Brasil, onde o édipo se refaz na história, se deduz o

operador antropológico que decifra o real coletivo. O alcance do chamado "Assassinato do pai" (Urmord) é tal, que ele reproduz ininterruptamente mais do "mito científico", o envelope formal que re-emerge na história real, onde deve-se saber reconhecê-lo em sua diversidade protei- 
forme. O "Assassinato do Pai" não é o elemento que a História precisa para resolver suas questões, é muito mais o curso da história que, nos seus momentos-chave, ensina os efeitos retroativos e recorrentes do Assassinato do Pai e de lhe dar materialidade. É isso que um ato, tal como esse que estudamos aqui nos coloca literalmente sob os olhos (Assoun, 2015, p. 22, tradução nossa) ${ }^{2}$.

\section{A nostalgia na universidade}

Não eram poucos os "órfãos" deste pai morto, representante da sociedade "patriarcal" que compartilhavam essa nostalgia que ocupou o cerne do pensamento nas instituições. Esse sentimento se impôs inclusive nos meios acadêmicos mais prestigiosos, protegido por teorias de grande respaldo; o suficiente para seus teóricos serem considerados, por muito tempo, como os grandes intérpretes da sociedade Brasileira. Jacino (2017) cita Gilberto Freyre, quem considera o grande fundador desta tradição que, como Sérgio Buarque de Holanda, seu seguidor, descrevia a escravidão brasileira como sendo benigna, amena, fraterna e protetora

... entre escravizadores e escravizados, (com o proprietário representando, no máximo, o papel de um patriarca severo) resultado de suposta "índole cordial" daqueles e de uma sujeição passiva destes (Jacino, 2017, p. 33).

Jacino lista outros autores que tomaram essa noção como paradigma "para interpretações do Brasil contemporâneo” (Jacino, 2017, p. 35). Para ele, a obra

Raízes do Brasil foi comentada e debatida por estudiosos como Alexandre Eulálio, Evaldo Cabral de Mello, Bolivar Lamounier, Antonio Arnoni Prado, Pedro Meira Monteiro, Robert Wegner, Antonio Candido, Raymundo Faoro, Maria Odila Leite da Silva Dias, Ilana Blaj, Ronaldo Vainfas, Luiz Dulci, entre outros. E, cabe-nos acrescentar, a quase totalidade dos estudos de caráter lauda- tório, com críticas muito pontuais, via de regra, corroborando as conclusões e buscando justificar os evidentes equívocos daquele historiador (Jacino, 2017, p. 35).

Jacino (2017) ainda comenta que esse pensamento embasou a disseminação do mito da "democracia racial" na qual se supõe que a sociedade patriarcal (leia-se escravista) era boa para as pessoas escravizadas, posição defendida inclusive com argumentos eugenistas. Nesse fantasma se vê um "pai" bondoso e cordial que mascara e protege a violência abominável da escravidão. Esse sentimento de amor puro e ausência de crítica à figura inconsciente do pai ilustra o recalque. Em 1929, no Mal-estar na civilização, Freud passa do mito do filho da horda primitiva, ao da criança saída do complexo de Édipo, para propor uma gênese do masoquismo:

não há renúncia pulsional .... A criança é forçada a abrir mão da agressividade vingativa. Para sair triunfante dessa situação economicamente complicada, ela recorre aos conhecidos mecanismos de identificação e se inculca o Supereu; autoridade idealizada e intangível, contra a qual ela teria preferido dirigir sua agressividade (Freud, 1929/2017, p. 74-75, tradução nossa).

Esse amor é sinalizado com a obediência à lei e, neste caso, o ódio recalcado pode ser sintomaticamente dirigido para o próximo. Pois a vida moral e o pensamento penal dos sujeitos é fundada sobre "a necessidade de expiação das exigências do sentimento de culpabilidade" (Freud, 1912/2013, p. 172, tradução nossa).

Os "nostálgicos" da escravidão repetem um mesmo movimento: camuflam o ódio protegendo, romanceando, elogiando e cultuando ao pai inconsciente atualizado no ideal escravista. Ignoram a realidade catastrófica e criminosa da escravidão, uma ingenuidade incompreensível, como essa de Bittencourt, mas sobre a qual a metapsicologia pode jogar certa luz. Ela dá sentido ao sentimento de ofensa e até ao mal-estar dos sujeitos que veem

\footnotetext{
${ }^{2}$ Assoun (2015) se refere ao seu estudo sobre a história da profanação do mausoléu onde foram "exumados um a um, em algumas semanas, os representantes do conjunto das dinastias que reinaram na França" (p. 14). Nesse momento da queda do regime monárquico, o comité revolucionário, órgão "representativo da vontade popular" (p. 8) organizou a ação na Basílica de Saint-Denis para enterrar os corpos da realeza nas "valas comuns da História" (p. 7). Para Assoun, esse é um momento onde o mito freudiano mais uma vez se refez "na história real, sobre a cena do teatro da Revolução" (p. 23).
} 
questionado o amor ao pai, no caso, atualizado na instituição do escravismo.

A passagem do sadismo escravocrata para a melancolia, como foi o caso para Novis, indica o momento constatado por Freud (1915/2004) no qual o sujeito angustiado descarrega sobre si um ódio endereçado até então a quem ele torturava e escravizava. Os destinos da pulsão, observa Freud (1915/2012), podem se dirigir para o próximo ou se voltar contra o sujeito, como no fantasma que pode tomar forma avessa, guardando o sentido. Incita a olhar ou a ser visto, ou ainda, bater e ser batido (Freud, 1919/1996).

\section{Bate-se numa criança, e numa pessoa negra}

Para Assoun (2010), o senso comum tende a ver o fantasma como um elemento insignificante, como se os fatos não dependessem dele. O olhar freudiano, entretanto, dá a entender que o fantasma da criança batida é um dos eixos da escravidão. Ele cita o best seller mundial A cabana do pai Tomás, no qual se humanizam as vítimas do escravismo em oposição ao discurso escravagista que animaliza humanos, descrevendo detalhadamente as crueldades deste crime: sequestro, tortura, abusos, agressões morais e sexuais. Nessa obra, as relações familiares têm um lugar central e a riqueza descritiva das violências, segundo os críticos, é a razão de sua popularidade (Parfait, 2010).

Freud (1919/1996) constata que o livro A cabana do pai Tomás é a obra mais mencionada entre seus pacientes, onde a cena fantasmática da criança batida se refaz no drama da escravidão. $\mathrm{O}$ aspecto mais fundamental desse fantasma que se refaz nos planos mais variados - nas práticas sexuais, na política, na literatura e nas regras sociais - é a mesma culpabilidade colocada por Freud, em 1929, como a fonte da hostilidade social.

O mal-estar na cultura da nostalgia brasileira se refazendo no sadismo ou no masoquismo, onde a culpabilidade faz que o sofrimento sinalize amor e o perdão do pai inconsciente, onde o pai bate porque ama ou ama porque bate.

\section{Melancolia na política}

Freud (1915/2004) vê a melancolia como uma versão patológica do luto ligada à perda do objeto, pois o sujeito reverte a libido destinada ao seu $\mathrm{Eu}$ identificado ao objeto. Ele estabelece um paralelo entre a política e a melancolia, indicando que o Eu se "rebela" ao perder o objeto. Segundo o dicionário do Centre National de Resources Textuelles et Lexicales (n. d.), rebela-se "contra a autoridade, contra o poder da ordem estabelecida". A perda demandaria a transferência da libido para outro objeto, mas na melancolia, "A intensidade dessa rebelião distorce a realidade ... e o objeto perdido perdura psiquicamente" (Freud, $1915 / 2004$, p. 8). Entretanto, o termo político adequado a essa melancolia seria reação, devido ao seu sentido reacionário.

O texto de outra escritora, também de sobrenome Bittencourt ${ }^{3}$, ilustra a presença dessa tristeza reacionária no meio senhoril, que se opõe ao sentido da história. O meio familiar de Anna Ribeiro Araújo de Goes Bittencourt era típico "de uma sociedade patriarcal e agrária: escravos, engenhos, barões (era sobrinha e prima de três dos mais poderosos e abastados da região)" (Oliveira, 2007a, p. 27), "sendo que as regiões onde eles ficavam levam seus nomes até os dias de hoje" (Oliveira, 2007a, p. 41). Bittencourt se referia à sua família como "uma espécie de aristocracia formada pela classe muito considerada dos senhores de engenho, que era a segunda nobreza do país, como era na França a magistratura" (Bittencourt citada por Oliveira, 2007b, p. 172). Ela privilegiou em sua obra a vida cotidiana da casa-grande em decadência após a abolição. Ela descreve em seu romance Letícia o personagem Travassos, pai da protagonista que foi, nos tempos da escravidão, um poderoso senhor de engenho. Adoecido na abolição, sentiu-se traído pelos que escravizou; perplexo, não compreendia como recusaram o trabalho depois de libertos. Logo ele que, como o barão de Santiago, acreditava sinceramente tê-los tratado "tão bem" (Bittencourt citada por Oliveira, 2008a, p. 20).

À imagem do barão de Santiago, o personagem fictício de Travassos também adoeceu com a "terrível labuta” (Bittencourt citada por Oliveira, 2008a, p. 20) que passou a ter depois do 13 de maio. Não conseguia submeter novamente as pessoas que escravizou ao mesmo trabalho. Vivia então prostrado, "em uma poltrona, imóvel, com o olhar fixo e profundamente triste, que inculcava refletir no infeliz estado em que se achava" (Bittencourt citada por Oliveira, 2008a,

${ }^{3}$ Seu meio familiar 
p. 20-21). Para Oliveira, estudioso da biografia e da obra de Bittencourt,

a consciência de que a tradicional ideologia senhorial de fato teria entrado em colapso, levou-o a se entregar e esperar a morte.... Travassos preferia a morte a ter que viver num mundo onde a ideologia senhorial não mais imperava .... O "infeliz estado em que se achava" era justamente a consciência de que toda sua vida senhorial, não mais existia (Oliveira, 2008b, p. 105).

Para Bittencourt o antigo senhor era

"vítima" desse processo, que teria sido desencadeado com a lei do 13 de maio. Em todo contexto do conto se quer passar uma idéia de que a "classe dos agricultores" fora injustiçada pelo Estado e por aqueles que no cativeiro foram "bem" tratados pelos antigos senhores com seus "favores" e “concessões” (Oliveira, 2008b, p. 67-68).

Tal interpretação da história era corrente desde os primeiros momentos da abolição e muito além da literatura. Efetivamente, ela refletia a posição de um determinado grupo social. Para o porta-voz de uma associação de fazendeiros, a lei Áurea foi "um ato sumário e arbitrário” (BPEB, citado por Mata, p. 16). O barão de Villa Viçosa ilustra essa posição no artigo "A lavoura da cana de açúcar, as causas de sua decadência nesta província e o seu estado depois da lei de 13 de maio", lamentando o drama das "mães de família qualificadas":

Quando mães de família qualificadas viram-se obrigadas a ir para as cozinhas, quando crianças ficaram sem amamentação [que lhes davam as amas de leite] ... estava eloquentemente demonstrado que a lei de 13 de maio era um ponto final à colheita da safra. Assim aconteceu: todos os engenhos pararam a moagem, perdendo-se no campo mais da metade das canas. ... É tristíssimo o que se passa no lar das famílias, que ontem cercadas de consideração e respeito, hoje não encontram senão a miséria, a falta de garantia, as lágrimas, o desespero e o suicídio! ... é horripilante ouvirem-se os gritos aterradores d'aqueles que passaram a ser vítimas, arrancando os cabelos, correndo loucos pelas estradas, cometendo os maiores desatinos, por se verem sem recursos para conservar a honra e o pudor de sua família! (BPEB, Diário da Bahia, 22 de julho de 1888, citado por Mata, 2002, p. 16-18)

Anna Ribeiro Bittencourt descreve o significado da abolição em seu meio. De fato, seu pai sucumbiu dessa melancolia e, segundo Oliveira, ela descreve a infelicidade e a humilhação de seu velho pela boca de uma personagem:

Meu pobre pai, cuja moléstia parecia conservar-se estacionária durante esses dezoito meses, como tenho te informado, apresenta ultimamente manifesta piora. O médico que o assiste, declarou-me que se aproximava rapidamente o desenlace fatal (Bittencourt citada por Oliveira, 2008b, p. 104).

O relato de Bittencourt observa também que a abolição não se resumiu à melancolia. Segundo ela, o antiabolicionismo fundou a República e a distorção dos significantes em seu texto reflete a tensão social:

Todos sabem que a revolução de 15 de Novembro que derrubou o Império, foi um movimento puramente militar . . . tradução do descontentamento originado pelo golpe de Estado dado pela Princesa ... medida que tão profundamente feriu a classe dos agricultores (Bittencourt citada por Oliveira, 2008b, p. 67).

Ela explica a melancolia de um de seus personagens, um antigo senhor:

O que, pois, dava causa às apreensões do bom lavrador? É que se dera o golpe de Estado, abolindo a escravidão ao Brasil, e ele temia pelos resultados já apreciados, ver a sua propriedade cair em decadência, pela falta de braços, e sua família querida experimentar as privações a que não estava habituada (Bittencourt citada por Oliveira, 2008b, p. 67).

Um "golpe", disse ela! Corrente nas tragédias, a apropriação do vocabulário é correlata à divisão das sociedades nos ideais que se opõem: "as mesmas palavras tomam sentidos opostos na boca dos protagonistas que as empregam, seguindo 
acepções diversas da língua religiosa, jurídica, política" (Vernant, 2006, p. 6). Segundo Bittencourt, a fundação da República foi uma "revolução", já que tinha por finalidade se opor à abolição, visando restituir o que teria lhes usurpado.

\section{O crime então ilegal}

Muitos antigos senhores não aceitaram a abolição, assim como os que se colocaram deliberadamente ao lado do crime. Desta forma,

descontentes e indignados com a lei, usaram o dispositivo da força, com esperança de fazer os ex-cativos permanecerem trabalhando nas lavouras nos mesmos moldes dos tempos da escravidão. Não tinham, portanto, qualquer intenção de perder a autoridade e "direitos" advindos da posição senhorial (Mata, 2002, p. 21-22).

Muitos antigos senhores continuaram escravizando após a abolição; continuaram a cometer este crime, sem a proteção equivocada da lei. $\mathrm{O}$ artigo publicado no 25 de agosto de 1888 no Diário da Bahia, "A escravidão de libertos", dá algumas informações sobre a dimensão desta "revolta":

Um dos assuntos que mais particularmente deve chamar a atenção e despertar os cuidados do governo, é o modo por que estão sendo tratados os libertos. Por mais de uma vez tem a imprensa ... reclamado contra violências de que são vítimas os novos cidadãos, da parte dos seus ex-senhores. ... [Eles] querem ainda reter nas suas fazendas, e obrigar a um trabalho não retribuído, homens que perante a lei são hoje tão senhores do seu trabalho, da sua vontade, como os seus antigos senhores (BPEB, citado por Mata, 2002, p. 21-24).

Inúmeras pessoas até então escravizadas "passaram a ser, após a aprovação da lei, alvo constante de violências e agressões" (Mata, 2002, p. 21). Uma circular emitida por um chefe da polícia comenta "que em diversos pontos do interior, os ex-senhores dos libertos despeitados com a lei, agarraram os exescravos e os espancaram em cárceres privados" (APEB citado por Mata, 2002, p. 20), assim como demonstra o seguinte caso: fora barbaramente surrado e supliciado Luciano Rodrigues dos Santos por Clementino José Ribeiro, tendo a vítima estado preso em cárcere privado por mais de 15 dias, tendo determinado semelhante procedimento o desespero em que ficou Clementino com a lei da abolição dos escravos; protestando desde logo que, se aquele infeliz não lhe servia mais, também havia de inutilizá-lo para que não servisse mais a si mesmo ... nem a outro (BPEB, Diário da Bahia 22/08/1888 citado por Mata, 2002, p. 24).

Um caso chama a atenção pela maneira com que ilustra essa dupla vertente da pulsão, ou ainda do desdobramento maníaco da melancolia:

casado em uma das famílias mais importantes deste município, e quase que posso dizer de maior força e prestígio. Foi sempre tido como homem de bem e respeitador da Lei e da sociedade; mas depois da áurea Lei de 13 de Maio deste ano, como que falto da resignação precisa para suportar o prejuízo que teve com a perda de alguns escravos, passou alguns dias triste, melancólico e pensativo, e depois de alguns dias que passou nessa prostração, apresenta-se em um estado de exaltação mental, que mais se elevava com o beber de espíritos alcoólicos e em grande quantidade, que o fazia exacerbar-se. Nesse estado então acercava-se de capangas e também bebedores, e tem cometido alguns desatinos no Rio Azul, na estação Timbó e ultimamente no Povoado da Cêpa Forte, termo de Abbadia, onde os moradores se viram obrigados a fecharem as portas aterrorizados e amedrontados com os desmandos desse senhor (Relatório policial, citado por Mata, 2002, p. 28).

\section{A responsabilização e trabalho de confissão}

O processo de responsabilização não é simples, requer um esforço considerável do sujeito $e$ das instituições. Do lado do sujeito, Theodor Reik (1925/1997) observou a necessidade de um trabalho de confissão que também tem sua complexidade; não se trata de uma mera confissão dos atos. Segundo Masson, 
O trabalho de confissão representa uma transformação psíquica fundamental do autor do ato, uma profunda mudança psíquica e subjetiva que produz efeitos de socialização, de reconhecimento mútuo e de reparação do traumatismo causado pelo crime, tanto no criminoso quanto na vítima (Masson, 2012, p. 195-196, tradução nossa).

Reik (1925/1997) indica que o trabalho de confissão requer um esforço comparável aos trabalhos de sonho e de luto, pois supõe o reconhecimento - ainda que parcial - dos fatos inconscientes que levam o sujeito ao crime, assim como à gravidade do ato. Esse primeiro esforço dá lugar ao remorso, posição na qual o sujeito encontra os meios subjetivos para reinterpretar o ato e o significado da reparação.

As instituições e sobretudo a lei, devem garantir o contexto simbólico que reconheça o status criminoso o ato. Tebas de Creonte compartilha com o Brasil escravista uma lei criminosa cuja natureza e responsabilidade foi negada. Um fato observado por Arendt ilustra a questão: Eichmann tenta se eximir de sua responsabilidade argumentando que era um cidadão exemplar, "meticulosamente" (Arendt, 1991, p. 48) obediente às leis e ordens superiores.

Antoine Masson, coloca a "noção de responsabilidade do ponto de vista da hipótese do inconsciente" (2012, p. 187, tradução nossa e grifos do autor) retomando posições divergentes no seio da sociedade analítica do século XX. Se Freud faz do crime um sintoma oriundo de recalque, cabe então a questão: o sujeito pode se responsabilizar por seus atos já que suas motivações são inconscientes?

Masson (2012) evoca a posição determinista de Marie Bonaparte (1952), na qual o psiquismo teria sua organização determinada com tal rigidez que o criminoso agiria sem conflito. Ela conclui que, por isso, "a palavra responsabilidade deveria ser excluída do Código" (Bonaparte, 1952, p. 39). Segundo Bonaparte, como seres da natureza, "nossos gestos, palavras, pensamentos são tão estritamente determinados quanto são os movimentos dos planetas e do sol nos espaços celestes" (Bonaparte, 1952, p. 44), logo, os termos "responsável e irresponsável, perdem seu sentido legal : deveria então se dizer encarcerável, ou internável" (Bonaparte, 1952, p. 45, tradução nossa e grifos do autor),

Masson (2012) contrapõe a opinião de Bonaparte à de Ferenczi (1928/1990, p. 235, tradução nossa), que se posiciona de outra maneira: "sobre a questão de saber se devemos nos responsabilizar por nossos atos pulsionais, Freud responde por uma desconcertante questão: o que se pode fazer além disso?". Ou seja, para Freud não há outra escolha possível que não a de abordar a responsabilidade do sujeito do crime frente aos seus atos pulsionais. Devendo-se trabalhar para que, gradualmente, ele "assuma a responsabilidade de seus atos inconscientes” (Masson, 2012, p. 191, tradução nossa).

Para se estabelecer, o trabalho de confissão precisa se apoiar na lei, nas instituições, na convenção e regulamentação social do crime para que se consiga estabelecer

uma relação interlocutória durante a qual um terceiro dará a justa retribuição ao ato, sendo que essa será sempre menos terrível que o traumatismo pulsional inicial ou o terror engendrado pela realidade fantasmática de um Supereu arcaico (Masson, 2012, p. 196, tradução nossa).

\section{Conclusão}

Os restos sintomáticos da história jogam luz sobre o motor inconsciente da morbidez e da tensão social. Por um lado, "a abolição aparece como um momento fundamental da trajetória pessoal” (Fraga Filho, 2007, p. 355) das pessoas libertadas; elas se diziam "encantadas", de "cabeça virada", já que, uma vez livres, pois "estavam decididas a criar as condições de subsistência para não viver sob sujeição" (Fraga Filho, 2007, p. 355, grifos do autor).

Os libertos do Recôncavo contavam ter acesso à uma parcela de terra para trabalhar para seu próprio benefício. Nostálgicos, os senhores decaídos se consideravam, entretanto, vítimas e não toleraram a liberdade e talvez menos ainda a ideia de igualdade simbolicamente colocada pela abolição. O mal-estar se manifestou imediatamente, no dia seguinte à abolição, no âmbito da política. Tal expressão do mal-estar se cristalizou no grande conjunto das instituições da República pela lógica sintomática de criminalização e perseguição do outro.

Na Assembleia Legislativa baiana,

No dia 14 de maio um parlamentar protesta na Assembleia da província contra a diminuição dos efetivos da polícia, grave erro aos seus olhos no 
momento onde perto de 80.000 pessoas acabavam de escapar do controle da ordem escravagista. As cidades do recôncavo e de outras regiões da província solicitaram ao chefe da polícia um aumento dos contingentes policiais (Fraga Filho, 2007, p. 320-321).

Com o ideal do escravismo morto instalou-se um movimento nostálgico contrário ao trabalho do luto e da melancolia, que depende da

renúncia do objeto e da declaração de sua morte ... oferecendo ao sujeito o benefício de permanecer vivo. Para relaxar a fixação libidinal no objeto, é preciso desvalorizá-lo, rebaixá-lo ou mesmo, feri-lo mortalmente. ... o objeto deve ser abandonado e reconhecido sem valor.... Assim o Eu pode saborear a satisfação de ser melhor e superior ao objeto (Freud, 1915/2004, p. 18, tradução nossa).

O título do artigo de Jacino (2017), "Que morra o homem cordial", remete ao trabalho de luto. Este trabalho contra a morbidez social permite que as identificações e ideais sociais não dirijam o ódio para a figura do próximo (como foi para o escravo), nem ao próprio Eu (como fez o antigo senhor melancólico), mas contra a própria o ideal nefasto do escravismo. Entretanto, o mal-estar da abolição continua instalado.

$\mathrm{O}$ pensamento freudiano indica um mal-estar, uma culpabilidade inconsciente que antecede as hostilidades sociais, como expostas pelo Atlas da violência 2019, que associei rapidamente ao mal-estar ligado ao momento histórico da abolição, que de certa maneira constitui um mito fundador - e gerador de criminalidade - da República. Para ser tratado, o mal-estar precisa ser interpretado pelo seu sintoma. Como tal, o crime sinaliza uma necessidade inconsciente de punição, uma "demanda inconsciente de lei" (Assoun, 2004, p. 31), para que o sujeito tenha as conduções para fazer o trabalho que demanda a "compulsão de confissão". O código penal atribui o valor simbólico adequado ao ato, ou seja, lhe confere o significado que a sociedade se acorda em lhe dar. Por isso, saliento que a adequação da lei também é questão de responsabilidade política, de cidadania, de coesão e organização social, fatos necessários para a promulgação da lei Taubira.

\section{Referências}

Aichhorn, A. (2005). Jeunes en souffrance : psychanalyse et éducation spécialisée. Champ social. (Originalmente publicado em 1925).

Araújo, R. S. (2014). Une étude psychopathologique de la haine de masses. Les origines mythiques de la violence policière au Brésil [Tese de doutorado, Universidade de Paris 7 - Diderot]. theses.fr. http://www.theses.fr/2014PA070050

Arendt, H. (1991). Eichmann à Jérusalem : Rapport sur la Banalité du Mal. (A. Guérin e M.-I. Brudny, Trads). Gallimard. (Originalmente publicado em 1966).

Assoun, P. -L. (1993). Freud et les sciences sociales. Armand Colin.

Assoun, P.-L. (2004).Linconscient du crime. Recherchesen psychanalyse, (2), 23-39.https://doi.org/10.3917/rep.002.0023.

Assoun, P. -L. (2010). Leçons psychanalytiques sur le fantasme. Economica; Anthropos.

Assoun, P. -L. (2015). Tuer le mort: le désir révolutionnaire. PUF.

Bonaparte, M. (1952). Le cas de madame Lefebvre. In M. Bonaparte, Psychanalyse et anthropologie (pp. 5-45). PUF.

Centre National de Resources Textuelles et Lexicales. (n. d.). Rebeller. In Centre National de Resources Textuelles et Lexicales. Recuperado em 4 de dezembro de $2020 \mathrm{de} \mathrm{http://cnrtl.fr/definition/se \% 20rebeller.}$

Ferenczi, S. (1990), Psychanalyse et criminologie. In S. Ferenczi, CEuvres complètes (tomo IV). Payot. (Originalmente publicado em 1928).

Fraga Filho, W. (2007). Le 13 mai 1888 et les jours qui suivent. Cahiers du Brésil Contemporain, 67/68, 315-361.

Fraga Filho, W. (2010). O 13 de maio e as celebrações da liberdade, Bahia, 1888-1893. História social, (19), 63-90.

Freud, S., \& Zweig, A. (1973). Correspondance 1927-1939. Gallimard.

Freud, S. (1996). Uma criança é espancada: uma contribuição ao estudo da origem das perversões sexuais. In S. Freud, Edição Standard brasileira das obras psicológicas completas de Sigmund Freud. (J. Salomão, Trad., v. 17, pp. 225-258). Imago. (Originalmente publicado em 1919). 
Freud, S. (2002). Psychologie collective et analyse du moi (S. Jankélévitch, Trad.). Université du Québec \& Chicoutimi. http://classiques.uqac.ca/classiques/freud_sigmund/essais_de_psychanalyse/Essai_2_psy_collective/Freud_ Psycho_collective.pdf. (Originalmente publicado em 1921).

Freud, S. (2004). Deuil et mélancolie (Jean Laplanche et J.B. Pontalis, Trads.). Sociétés, 86(4), 7-19. https://doi. org/10.3917/soc.086.0007. (Originalmente publicado em 1915).

Freud, S. (2012). Pulsions et destins des pulsions. (O. Mannoni, Trad.) Payot. (Originalmente publicado em 1915).

Freud, S. (2013). Totem et tabou. Interprétation par la psychanalyse de la vie sociale des peuples primitifs. (S. Jankélévitch, Trad.). Université du Québec \& Chicoutimi. http://classiques.uqac.ca/classiques/freud_ sigmund/totem_tabou/totem_et_tabou_SV.pdf. (Originalmente publicado em 1912).

Freud, S. (2017). Malaise dans la civilisation (Ch. e J. Odier, Trads.). Université du Québec \& Chicoutimi. http://classiques.uqac.ca/classiques/freud_sigmund/malaise_civilisation/malaise_civilisation.pdf. (Originalmente publicado em 1929).

Instituto de Pesquisa Econômica Aplicada. (2019). Atlas da violência 2019. https://www.ipea.gov.br/portal/images/ stories/PDFs/relatorio_institucional/190605_atlas_da_violencia_2019.pdf

Jacino, R. (2017). Que morra o "homem cordial" - crítica ao livro Raízes do Brasil, de Sérgio Buarque de Holanda. Sankofa, 10(19), 33-63. https://doi.org/10.11606/issn.1983-6023.sank.2017.137189

Lacan J. (1966) Introduction théorique aux fonctions de la psychanalyse en criminologie. In J. Lacan, Ecrits (pp. 125-149). Seuil.

Lacan, J. (1986). Le séminaire, livre VII: l'éthique de la psychanalyse (1959-1960). Seuil.

Loi n 2001-434 du 21 mai 2001 tendant à la reconnaissance de la traite et de l'esclavage en tant que crime contre l'humanité. (2001). https://www.legifrance.gouv.fr/affichTexte.do?cidTexte=JORFTEXT000000405369

Lemos, F. C. S., Aquime R. H. S., Franco, A. C. F., \& Piani, P. P. F. (2017). O extermínio de jovens negros pobres no Brasil: práticas biopolíticas em questão. Pesquisas e Práticas Psicossociais, 12(1), 164-176.

Masson, A. (2012). Du travail de l'aveu à la flexibilité des sanctions: quelle plasticité? In D. Kaminski (Ed.), La flexibilité des sanctions: XXIes journées juridiques Jean Dabin (pp. 187-205). Bruylant.

Mata, I. M. (2002). Os "treze de maio": ex-senhores, polícia e libertos na Bahia pós-abolição (1888-1889) [Dissertação de mestrado, Universidade Federal da Bahia]. Programa de Pós-Graduação em História UFBA. https://ppgh.ufba.br/sites/ppgh.ufba.br/files/7_os_treze_de_maio_-_ex-senhores_policia_e_libertos_na_ bahia_pos-abolicao._1888-1889.pdf

Oliveira, M. S. (2007a). Fios literários na teia da História: paternalismo, escravidão e pós-abolição num romance de Anna Ribeiro. Em tempo de histórias, (11), 25-42.

Oliveira, M. S. (2007b). História, literatura e mercado literário na Bahia oitocentista: o projeto de Anna Ribeiro Góes Bittencourt (1843-1930). A Cor das Letras, (8), 171-182.

Oliveira, M. S. (2008a). Fios literários na teia da História: paternalismo, escravidão e pós-abolição num romance de Anna Ribeiro. Outros Tempos, 5(6), 15-32.

Oliveira, M. S. (2008b). Uma senhora de engenho no mundo das letras: odeclínio senhorial em Anna Ribeiro [Dissertação de mestrado, Universidade Estadual da Bahia]. Domínio Público. http://www.dominiopublico.gov.br/pesquisa/ DetalheObraForm.do?select_action=\&co_obra=136907.

Parfait, C. (2010). Un succès américain en France: La Case de l'Oncle Tom. E-rea, 7(2). https://doi.org/10.4000/erea.981.

Reik, T. (1997). Le besoin d'avouer: psychanalyse du crime et du châtiment. Payot. (Originalmente publicado em 1925).

Sacramento, C. A. (2007). Mundos do Trabalho no Recôncavo Sul: Cotidiano, trabalhadores, costumes, conflitos e solidariedades. 1879 - 1910 [Dissertação de mestrado, Universidade Federal da Bahia]. Repositório UFBA. https://repositorio.ufba.br/ri/bitstream/ri/11116/1/Dissertacao\%20Cleidivaldo\%20Sacramentoseg.pdf

Taubira, C. (1999). Invitée: Christiane Taubira-Delannon + dossier esclavage (H. Camouilly, Entrevistadora) [Vídeo]. https://www.ina.fr/video/CAC99008937.

Vernant, J.-P. (2006). Edipe sans complexe. In Vernant J.-P., \& Vidal-Naquet P. , Edipe et ses mythes. Complexe. 


\section{Renato Sarieddine Araújo}

Pesquisador doPSILACS do Departamento depsicologia daUniversidadeFederal de Minas Gerais, BeloHorizonte-MG.

Brasil.

E-mail: renatosarieddine@gmail.com

(D) https://orcid.org/0000-0002-3993-333X

Agradeço a leitura e comentários cuidadosos de Marcelo Ricardo Pereira, Omar David Moreno Cardenas, José Newton Garcia de Araujo e Pedro Lotti Carvalho Dias.

Endereço para envio de correspondência:

Rua Grão Pará 1060/101, Funcionários. CEP: 30150-341, Belo Horizonte-MG. Brasil.

Recebido 18/10/2019

Aceito 18/10/2019

Received 10/18/2019

Approved 10/18/2019

Recibido 18/10/2019

Aceptado 18/10/2019

Como citar: Araújo, R. S. (2020). Uma Lei Contra o Crime Escravista e o Mal-Estar da Abolição. Psicologia: Ciência e Profissão, 40 (n.spe), 1-14. https://doi.org/10.1590/1982-3703003230121

How to cite: Araújo, R. S. (2020). A Law Against the Crime of Slavery and the Abolition's Discontent. Psicologia: Ciência e Profissão, 40 (n.spe), 1-14. https://doi.org/10.1590/1982-3703003230121

Cómo citar: Araújo, R. S. (2020). Una Ley Contra el Crimen Esclavista y el Malestar de la Abolición. Psicologia: Ciência e Profissão, 40 (n.spe), 1-14. https://doi.org/10.1590/1982-3703003230121 